\title{
Preparation, structure, and reactivity of bicyclic benziodazole: a new hypervalent iodine heterocycle
}

\author{
Akira Yoshimura*1,2, Michael T. Shea ${ }^{2}$, Cody L. Makitalo ${ }^{2}$, Melissa E. Jarvi², \\ Gregory T. Rohde ${ }^{3}$, Akio Saito ${ }^{4}$, Mekhman S. Yusubov ${ }^{1}$ and Viktor V. Zhdankin ${ }^{* 1,2}$
}

\section{Full Research Paper}

\section{Address:}

${ }^{1}$ The Tomsk Polytechnic University, 634050 Tomsk, Russia, ${ }^{2}$ Department of Chemistry and Biochemistry, University of Minnesota, Duluth, MN 55812, USA, ${ }^{3}$ Marshall School, Duluth, MN 55811, USA, and ${ }^{4}$ Division of Applied Chemistry, Institute of Engineering, Tokyo University of Agriculture and Technology, 2-24-16 Naka-cho, Koganei, Tokyo 184-8588, Japan

\section{Email:}

Akira Yoshimura* - ayoshimu@d.umn.edu; Viktor V. Zhdankin* -

vzhdanki@d.umn.edu

* Corresponding author

Keywords:

benziodazole; biheterocycles; hypervalent iodine; iodine; oxidatively assisted esterification
Beilstein J. Org. Chem. 2018, 14, 1016-1020. doi:10.3762/bjoc. 14.87

Received: 06 February 2018

Accepted: 20 April 2018

Published: 08 May 2018

This article is part of the Thematic Series "Hypervalent iodine chemistry in organic synthesis".

Guest Editor: T. Wirth

(C) 2018 Yoshimura et al.; licensee Beilstein-Institut. License and terms: see end of document.

\begin{abstract}
A new bicyclic organohypervalent iodine heterocycle derivative of benziodazole was prepared by oxidation of 2-iodo- $N$, $N$ '-diisopropylisophthalamide with $m$-chloroperoxybenzoic acid under mild conditions. Single crystal X-ray crystallography of this compound revealed a five-membered bis-heterocyclic structure with two covalent bonds between the iodine atom and the nitrogen atoms. This novel benziodazole is a very stable compound with good solubility in common organic solvents. This compound can be used as an efficient reagent for oxidatively assisted coupling of carboxylic acids with alcohols or amines to afford the corresponding esters or amides in moderate yields.
\end{abstract}

\section{Introduction}

In recent years, the interest in heterocyclic organohypervalent iodine compounds has experienced an unprecedented growth [1-6]. A variety of new hypervalent iodine heterocycles have been prepared, and numerous reactions employing these compounds as reagents for organic synthesis have been reported. The benziodoxole-based five-membered iodine heterocycles represent a particularly important class of hypervalent iodine(III) reagents. Substituted benziodoxoles 1 (Scheme 1a) are commonly employed as efficient electrophilic atom-transfer reagents useful for conversion of various organic substrates to the corresponding products of azidation [7-11], amination [12,13], cyanation [14-17], alkynylation [18-20], or chlorination $[21,22]$. Recently, Zhang and co-workers reported the preparation of several bicyclic benziodoxoles 3 starting from 2-iodoisophthalic acid (2, Scheme $1 \mathrm{~b})$. These bicyclic benziodoxoles $\mathbf{3}$ can be used as efficient coupling reagents for the 
a) monocyclic benziodoxolones<smiles>[X]I1OC(=O)c2ccccc21</smiles>

atom-transfer reagent $\mathrm{X}=\mathrm{N}_{3}, \mathrm{NHR}, \mathrm{CN}$, alkynyl, $\mathrm{Cl}$

c) monocyclic benziodazoles

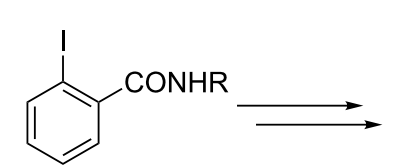

4<smiles></smiles>

5 oxidative reagent

$\mathrm{X}=\mathrm{AcO}, \mathrm{N}_{3} ; \mathrm{R}=\mathrm{H}$, alkyl, $\mathrm{CH}(\mathrm{Me}) \mathrm{CO}_{2} \mathrm{Me}$, etc. b) bicyclic benziodoxol(on)es

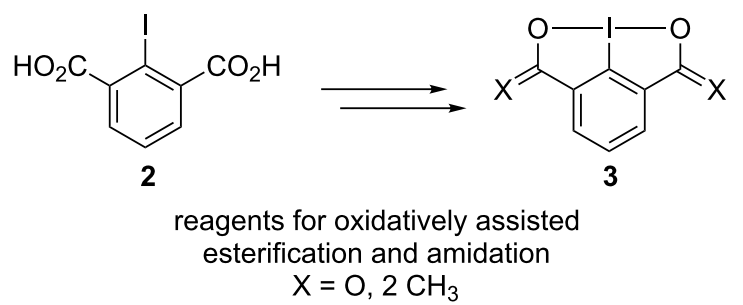

d) bicyclic benziodazoles<smiles>[R]NC(=O)c1cccc(C(=O)O[R])c1I</smiles><smiles>[R]N1C(=O)c2cccc3c2I1N([R])C3=O</smiles>
7

this work

direct condensation reaction between carboxylic acids and alcohols or amines to provide esters, macrocyclic lactones, or amides and peptides [23-25].

Numerous examples of five-membered hypervalent iodine(III) heterocycles containing other than oxygen heteroatoms, such as sulfur [26], boron [27,28], phosphorous [29], or nitrogen [30-32], have been synthesized and characterized by X-ray crystallography. In particular, several nitrogen containing heterocyclic iodine(III) compounds $\mathbf{5}$, benziodazoles, have been reported by Gougoutas [31], Balthazor [32], and our group [33-35] (Scheme 1c). X-ray structural studies of these benziodazoles confirmed the presence of covalent bonding between iodine and nitrogen atoms in the heterocyclic ring. Benziodazoles $\mathbf{5}$ are usually prepared by the treatment of 2-iodobenzamide derivatives 4 with appropriate oxidants under mild conditions [31-35]. Derivatives of benziodazole can be used as reagents for various oxidative functionalizations of organic substrates $[33,36]$. For example, azidobenziodazole was used as an efficient azidation reagent with a reactivity similar to azidobenziodoxoles [33]. Recently, the Wang group reported a rhenium catalyst-mediated oxidative dehydrogenative olefination of a $\mathrm{C}\left(\mathrm{sp}^{3}\right)-\mathrm{H}$ bond using acetoxybenziodazole reagents [36]. To the best of our knowledge, all known benziodazoles have a mono-heterocyclic structure, and bi-heterocyclic benziodazole derivatives similar to the bicyclic benziodoxole 3 have never been reported. In this paper, we report the synthesis, structural characterization, and reactivity of a novel bicyclic benziodazole derivative 7 (Scheme 1d).

\section{Results and Discussion}

An obvious approach to the preparation of bicyclic benziodazoles 7 involves the oxidation of the corresponding 2-iodo$N, N$ '-dialkylisophthalamides 6 (Scheme 1). We have synthesized the precursors 6 in two simple steps starting from commercially available 2-iodoisophthalic acid (2). Firstly, 2-iodoisophthalic acid (2) was converted to the corresponding acyl chloride 8 by treatment with thionyl chloride (Scheme 2).

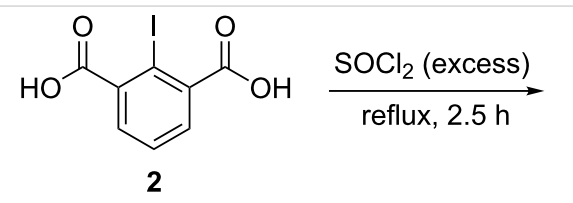<smiles>CC(C)NC(=O)c1cccc(C(=O)NC(C)C)c1I</smiles>

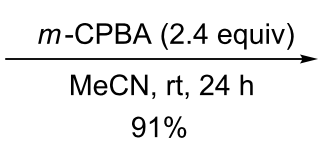

$6 a$<smiles>O=C(Cl)c1cccc(C(=O)Cl)c1I</smiles>
$\underset{\mathrm{MeCN}, 0^{\circ} \mathrm{C}, 1 \mathrm{~h}}{\stackrel{\mathrm{RNH}_{2} \text { (5 equiv) }}{\longrightarrow}}$<smiles>CC(C)N1C(=O)c2cccc3c2I1N(C(C)C)C3=O</smiles>

$7 a$<smiles>[R]NC(=O)c1cccc(C(=O)N[R])c1I</smiles>

$6 a-c$

6a: $R=i \operatorname{Pr}(90 \%)$

6b: $\mathrm{R}=n-\mathrm{C}_{6} \mathrm{H}_{13}(74 \%)$

6c: $\mathrm{R}=c-\mathrm{C}_{6} \mathrm{H}_{11}(90 \%)$

Scheme 2: Preparation of bicyclic benziodazole 7a 
In the second step, acyl chloride $\mathbf{8}$ reacted with appropriate alkylamines to give the corresponding 2-iodo- $N, N^{\prime}$-dialkylisophthalamides 6 in good yields. The oxidation of 2-iodo$N, N$ '-diisopropylisophthalamide (6a) with $m$-chloroperoxybenzoic acid ( $m$ CPBA) under mild conditions afforded the desired bicyclic benziodazole 7a in good yield. Unfortunately, we could not obtain the corresponding pure benziodazole derivatives 7 by the oxidation of precursors $\mathbf{6 b}$ or $\mathbf{6 c}$ under similar conditions. According to NMR spectra of the reaction mixture of $6 \mathbf{b}$ or $6 \mathbf{c}$, the desired products $7 \mathbf{b}$ or $7 \mathbf{c}$ were observed in the reaction as a complex mixture with other compounds. Bicyclic benziodazole 7a is a thermally stable, white, microcrystalline compound that can be stored in a refrigerator for several weeks. Solutions of $7 \mathbf{a}$ in $\mathrm{CDCl}_{3}$ or $\mathrm{CD}_{3} \mathrm{CN}$ did not show any decomposition even after storage for over one month at room temperature.

The solid state structure of compound $7 \mathbf{a}$ was characterized by X-ray crystallography. A single crystal X-ray diffraction of 7a confirmed the bicyclic benziodazole structure with two covalent bonds between the iodine atom and the nitrogen atoms $\mathrm{I}(1)-\mathrm{N}(1)=2.184$ (4) $\AA, \mathrm{I}(1)-\mathrm{N}(2)=2.177$ (4) $\AA$ (Figure 1). These bond lengths are similar to previously reported benziodazole structures [29-32]. According to X-ray crystallography data, structure 7a has a distorted T-shaped geometry with an $\mathrm{N}(1)-\mathrm{I}(1)-\mathrm{N}(2)$ angle of $153.90(15)^{\circ}$. Compared to other reported bicyclic hypervalent iodine compounds [23,25,37], this is the most bent structure at the $\mathrm{N}(1)-\mathrm{I}(1)-\mathrm{N}(2)$ angle. An additional relatively weak intermolecular coordination between the iodine atom and the oxygen atom of a neighboring molecule $\left(\mathrm{I}(1) \cdots \mathrm{O}^{\prime}(1)=3.107\right.$ (3) $\AA$ ) results in the overall pseudo-square planar geometry at the iodine center.

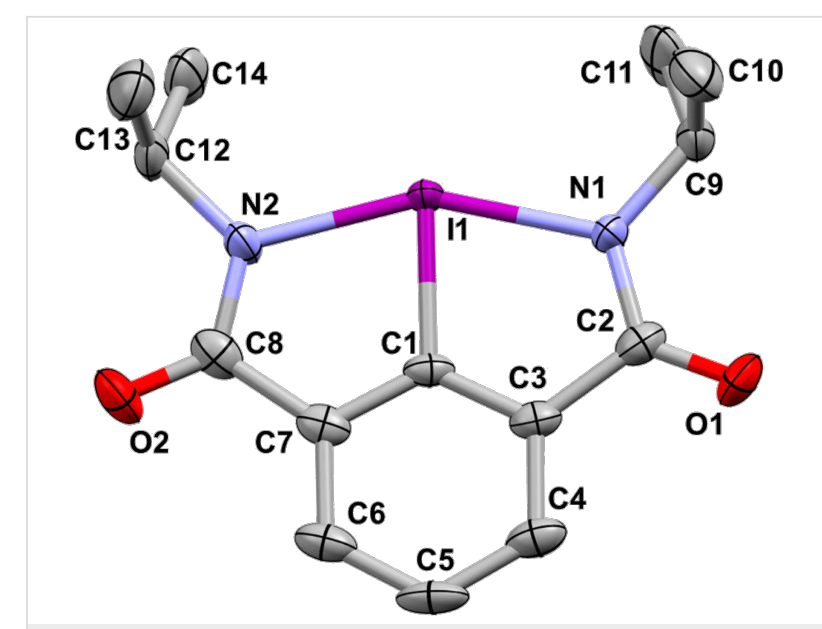

Figure 1: X-ray crystal structure of compound 7a. Ellipsoids are drawn to the $50 \%$ probability level. Selected bond lengths and angles: $\mathrm{I}(1)-\mathrm{C}(1) 2.040$ (4) $\AA$; I(1)-N(1) 2.184 (4) $\AA$; I(1)-N(1) 2.177 (4) $\AA$; $\mathrm{N}(1)-\mathrm{I}(1)-\mathrm{C}(1) 76.89(18)^{\circ} ; \mathrm{N}(2)-\mathrm{I}(1)-\mathrm{C}(1) 77.02(18)^{\circ} ; \mathrm{N}(1)-\mathrm{I}(1)-\mathrm{N}(2)$ $153.90(15)^{\circ}$

Similar to the iodosodilactone reagents [23-25], the bicyclic benziodazole 7 a could be expected to be a useful reagent for oxidatively assisted coupling reactions. Previously, Zhang and co-workers reported the reactions of carboxylic acids with alcohols or amines in the presence of stoichiometric amounts of iodosodilactones $\mathbf{3}$ forming the corresponding esters or amides in moderate to good yields via an oxidatively assisted coupling reaction [23-25]. We have investigated the analogous oxidatively assisted coupling reaction of carboxylic acids 9 with alcohols $\mathbf{1 0}$ or amine 12 using benziodazole 7a under similar conditions (Scheme 3). The reaction of butyric acid (9a) with benzyl alcohol (10a) using benziodiazole 7a in the presence of triphenylphosphine and $N, N$-dimethyl-4-aminopyridine (DMAP)

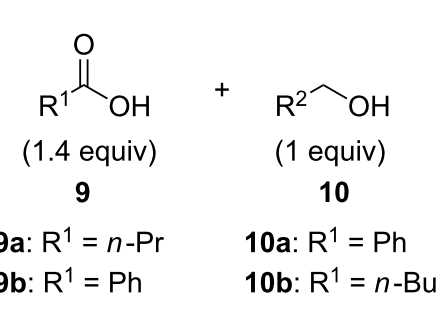

7a (1.2 equiv), $\mathrm{PPh}_{3}$ (1 equiv), $\underset{\mathrm{CHCl}_{3}, \text { reflux, } 24 \mathrm{~h}}{\mathrm{DMAP}(1.2 \text { equiv) }}$

$\mathrm{CHCl}_{3}$, reflux, $24 \mathrm{~h}$
11a: $90 \% ; \mathrm{R}^{1}=n-\mathrm{Pr}, \mathrm{R}^{2}=\mathrm{Ph}$
11b: $50 \% ; R^{1}=P h, R^{2}=P h$
11c: $55 \% ; \mathrm{R}^{1}=\mathrm{Ph}, \mathrm{R}^{2}=n-\mathrm{Bu}$

$$
\begin{gathered}
\mathrm{R}^{1}{ }^{1} \mathrm{O}_{\mathrm{O}} \\
11
\end{gathered} \mathrm{R}^{2} \text { (reaction 1) }
$$

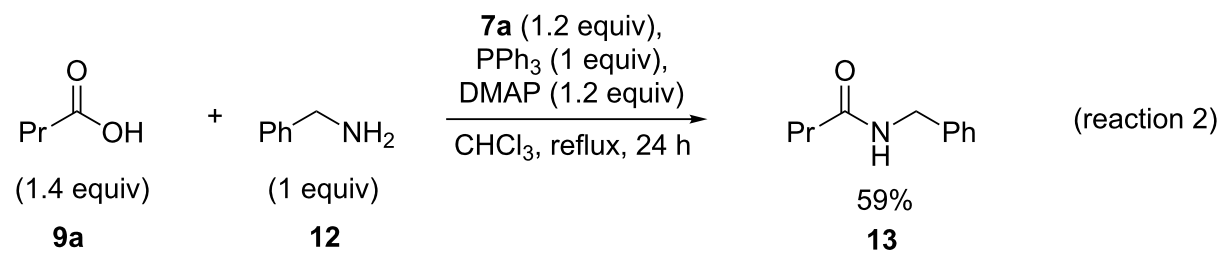


in chloroform solution under reflux conditions afforded the desired product 11a in good yield. As expected, the reactions of benzoic acid (9b) with benzyl alcohol (10a) or 1-pentanol (10b) under the same conditions gave the corresponding esters $\mathbf{1 1 b}$ or $11 \mathrm{c}$ in moderate yields (Scheme 3, reaction 1). The analogous reaction of butyric acid (9a) with benzylamine (12) and benziodazole 7a under similar conditions produced the expected amide 13 in moderate yield (Scheme 3, reaction 2). Compared to the iodosodilactone reagents 3 [23-25], benziodazole 7a showed a comparable or better reactivity. In contrast to iodosodilactone, benziodazole 7a has excellent solubility in chloroform allowing reactions in solution under homogeneous conditions. Similar to the reactions of iodosodilactone $\mathbf{3}$, $\mathrm{Ph}_{3} \mathrm{P}=\mathrm{O}$ and amide $6 \mathrm{a}$ were observed as the byproducts in these reactions (Scheme 3 ), which is in agreement with the previously proposed mechanism of oxidatively assisted esterification or amidation $[23,38]$.

\section{Conclusion}

In summary, we have prepared the new bicyclic benziodazole 7a by the oxidation of 2-iodo- $N, N$ '-diisopropylisophthalamide (6a) with $m$-CPBA. The solid structure of $7 \mathbf{a}$ was established by $\mathrm{X}$-ray crystallography. According to the X-ray data, this compound has a bis-heterocyclic structure with two covalent iodine-nitrogen bonds and distorted T-shape geometry at the hypervalent iodine center. This novel bicyclic benziodazole can be used as an efficient reagent for oxidatively assisted coupling of carboxylic acids with alcohols or amines to afford the corresponding esters or amides in moderate to good yields.

\section{Supporting Information}

\author{
Supporting Information File 1 \\ Experimental section. \\ [https://www.beilstein-journals.org/bjoc/content/ \\ supplementary/1860-5397-14-87-S1.pdf]

\section{Supporting Information File 2} \\ $\mathrm{X}$-ray structure of $\mathbf{7 a}$. \\ [https://www.beilstein-journals.org/bjoc/content/ \\ supplementary/1860-5397-14-87-S2.cif]
}

\section{Acknowledgements}

This work was supported by a research grant from the Russian Science Foundation (RSF-16-13-10081). A.S. is also thankful to JSPS Grant-in-Aid for Scientific Research (C, Grant No 15K07852) and to the JSPS Fund for the Promotion of Joint International Research (Grant No 16KK0199). V.V.Z. is thankful for support from the Office of the Vice President for Research, University of Minnesota.

\section{ORCID ${ }^{\circledR}$ iDs}

Akira Yoshimura - https://orcid.org/0000-0002-2577-397X Gregory T. Rohde - https://orcid.org/0000-0001-7787-8012 Akio Saito - https://orcid.org/0000-0002-8291-2059 Mekhman S. Yusubov - https://orcid.org/0000-0001-9233-1824 Viktor V. Zhdankin - https://orcid.org/0000-0002-0315-8861

\section{References}

1. Li, Y.; Hari, D. P.; Vita, M. V.; Waser, J. Angew. Chem., Int. Ed. 2016, 55, 4436-4454. doi:10.1002/anie.201509073

2. Yoshimura, A.; Zhdankin, V. V. Chem. Rev. 2016, 116, 3328-3435. doi:10.1021/acs.chemrev.5b00547

3. Le Vaillant, F.; Waser, J. Chimia 2017, 71, 226-230. doi:10.2533/chimia.2017.226

4. Charpentier, J.; Früh, N.; Togni, A. Chem. Rev. 2015, 115, 650-682. doi:10.1021/cr500223h

5. Zhdankin, V. V. Adv. Heterocycl. Chem. 2015, 115, 1-91. doi:10.1016/bs.aihch.2015.03.003

6. Wang, X.; Studer, A. Acc. Chem. Res. 2017, 50, 1712-1724. doi:10.1021/acs.accounts.7b00148

7. Zhdankin, V. V.; Krasutsky, A. P.; Kuehl, C. J.; Simonsen, A. J.; Woodward, J. K.; Mismash, B.; Bolz, J. T. J. Am. Chem. Soc. 1996, 118, 5192-5197. doi:10.1021/ja954119x

8. Krasutsky, A. P.; Kuehl, C. J.; Zhdankin, V. V. Synlett 1995, 1081-1082. doi:10.1055/s-1995-5173

9. Sharma, A.; Hartwig, J. F. Nature 2015, 517, 600-604. doi:10.1038/nature14127

10. Shinomoto, Y.; Yoshimura, A.; Shimizu, H.; Yamazaki, M.; Zhdankin, V. V.; Saito, A. Org. Lett. 2015, 17, 5212-5215. doi:10.1021/acs.orglett.5b02543

11. Alazet, S.; Le Vaillant, F.; Nicolai, S.; Courant, T.; Waser, J. Chem. - Eur. J. 2017, 23, 9501-9504. doi:10.1002/chem.201702599

12. Hu, X.-H.; Yang, X.-F.; Loh, T.-P. ACS Catal. 2016, 6, 5930-5934. doi:10.1021/acscatal.6b02015

13. Zhdankin, V. V.; McSherry, M.; Mismash, B.; Bolz, J. T.; Woodward, J. K.; Arbit, R. M.; Erickson, S. Tetrahedron Lett. 1997, 38, 21-24. doi:10.1016/S0040-4039(96)02245-9

14. Ma, B.; Lin, X.; Lin, L.; Feng, X.; Liu, X. J. Org. Chem. 2017, 82, 701-708. doi:10.1021/acs.joc.6b02726

15. Zhdankin, V. V.; Kuehl, C. J.; Krasutsky, A. P.; Bolz, J. T.; Mismash, B.; Woodward, J. K.; Simonsen, A. J. Tetrahedron Lett. 1995, 36, 7975-7978. doi:10.1016/0040-4039(95)01720-3

16. Le Vaillant, F.; Wodrich, M. D.; Waser, J. Chem. Sci. 2017, 8 , 1790-1800. doi:10.1039/C6SC04907A

17. Wang, Y.-F.; Qiu, J.; Kong, D.; Gao, Y.; Lu, F.; Karmaker, P. G.; Chen, F.-X. Org. Biomol. Chem. 2015, 13, 365-368. doi:10.1039/C4OB02032D

18. Hari, D. P.; Waser, J. J. Am. Chem. Soc. 2017, 139, 8420-8423. doi:10.1021/jacs.7b04756

19. Shen, K.; Wang, Q. Chem. Sci. 2017, 8, 8265-8270. doi:10.1039/C7SC03420B

20. Wodrich, M. D.; Caramenti, P.; Waser, J. Org. Lett. 2016, 18, 60-63. doi:10.1021/acs.orglett.5b03241

21. Wang, M.; Zhang, Y.; Wang, T.; Wang, C.; Xue, D.; Xiao, J. Org. Lett. 2016, 18, 1976-1979. doi:10.1021/acs.orglett.6b00547

22. Egami, H.; Yoneda, T.; Uku, M.; Ide, T.; Kawato, Y.; Hamashima, Y. J. Org. Chem. 2016, 81, 4020-4030. doi:10.1021/acs.joc.6b00295 
23. Tian, J.; Gao, W.-C.; Zhou, D.-M.; Zhang, C. Org. Lett. 2012, 14, 3020-3023. doi:10.1021/ol301085v

24. Zhang, C.; Liu, S.-S.; Sun, B.; Tian, J. Org. Lett. 2015, 17, 4106-4109. doi:10.1021/acs.orglett.5b02045

25. Gao, W.-C.; Zhang, C. Tetrahedron Lett. 2014, 55, 2687-2690. doi:10.1016/j.tetlet.2014.03.034

26. Koser, G. F.; Sun, G.; Porter, C. W.; Youngs, W. J. J. Org. Chem. 1993, 58, 7310-7312. doi:10.1021/jo00077a071

27. Nemykin, V. N.; Maskaev, A. V.; Geraskina, M. R.; Yusubov, M. S.; Zhdankin, V. V. Inorg. Chem. 2011, 50, 11263-11272. doi:10.1021/ic201922n

28. Yoshimura, A.; Fuchs, J. M.; Middleton, K. R.; Maskaev, A. V.; Rohde, G. T.; Saito, A.; Postnikov, P. S.; Yusubov, M. S.; Nemykin, V. N.; Zhdankin, V. V. Chem. - Eur. J. 2017, 23, 16738-16742. doi:10.1002/chem.201704393

29. Balthazor, T. M.; Miles, J. A.; Stults, B. R. J. Org. Chem. 1978, 43, 4538-4540. doi:10.1021/jo00417a037

30. Ohwada, T.; Tani, N.; Sakamaki, Y.; Kabasawa, Y.; Otani, Y.; Kawahata, M.; Yamaguchi, K. Proc. Natl. Acad. Sci. U. S. A. 2013, 110, 4206-4211. doi:10.1073/pnas.1300381110

31. Naae, D. G.; Gougoutas, J. Z. J. Org. Chem. 1975, 40, 2129-2131. doi:10.1021/jo00902a027

32. Balthazor, T. M.; Godar, D. E.; Stults, B. R. J. Org. Chem. 1979, 44, 1447-1449. doi:10.1021/jo01323a018

33. Zhdankin, V. V.; Arbit, R. M.; McSherry, M.; Mismash, B.; Young, V. G. J. Am. Chem. Soc. 1997, 119, 7408-7409. doi:10.1021/ja971606z

34. Zhdankin, V. V.; Koposov, A. E.; Smart, J. T.; Tykwinski, R. R.; McDonald, R.; Morales-Izquierdo, A. J. Am. Chem. Soc. 2001, 123, 4095-4096. doi:10.1021/ja0155276

35. Zhdankin, V. V.; Koposov, A. Y.; Su, L.; Boyarskikh, V. V.; Netzel, B. C.; Young, V. G. Org. Lett. 2003, 5, 1583-1586. doi:10.1021/ol0344523

36. Gu, H.; Wang, C. Org. Biomol. Chem. 2015, 13, 5880-5884. doi:10.1039/C5OB00619H

37. Nguyen, T. T.; Wilson, S. R.; Martin, J. C. J. Am. Chem. Soc. 1986, 108, 3803-3811. doi:10.1021/ja00273a041

38. The reaction of $7 \mathbf{a}$ in the presence of DMAP did not show any shift in the NMR spectrum probably because of a weak interaction between $7 \mathrm{a}$ and DMAP.

\section{License and Terms}

This is an Open Access article under the terms of the Creative Commons Attribution License (http://creativecommons.org/licenses/by/4.0), which permits unrestricted use, distribution, and reproduction in any medium, provided the original work is properly cited.

The license is subject to the Beilstein Journal of Organic Chemistry terms and conditions: (https://www.beilstein-journals.org/bjoc)

The definitive version of this article is the electronic one which can be found at: doi:10.3762/bjoc. 14.87 